\title{
Novel Coronavirus (Covid-19): It's Implication for Improving Discipline, Manner, and Skills
}

\author{
Shyam Bahadur Chhatkuli ${ }^{1}$ and Uttam Ariyal ${ }^{2}$
}

${ }^{1,2}$ Assistant Professor, Makawanpur Multiple Campus, Hetauda, Nepal

\section{Corresponding Author}

Uttam Ariyal

Email: uttamaryal1000@gmail.com

\section{ABSTRACT}

The research explores the implication of difficulties including lockdown caused by COVID-19 virus in improving discipline, manner, and skills for the development of society for independency. It studies a very backward village, Aambhanjyang, a village developing towards the city and a provincial capital city. It has not only the dark side by COVID-19 virus but also has a bright side for social development. With the study of its nature, human gains skills, develop a manner of self-discipline, and does the correction in culture. The changes may bring the dependent society into an independent society. The people from all the three types of location were not used to for the habits which prevent several types of communicable diseases passing from each other. It can be concluded that the difficult circumstances compel/opportune human to exist and combat with the new problems. Findings help society to be skilled in health care, mannered in behaving with each others, skilled for performing good and useful habits. Because of the changes, the skills, manner, habits make people disciplined and the discipline changes into tradition and finally the tradition become culture.

\section{KEYWORDS}

Coronavirus, COVID-19, Independent, Lockdown, Society

\section{INTRODUCTION}

Human is in lockdown condition worldwide because of a new virus. WHO has identified it as Novel Coronavirus COVID-19 (Sahin, Erdogan, Agaoglu, Dineri, \& Cakirci, 2020). It is a new virus because no previous vaccines are matching for the process of preventing it (Ghebreyesus, 2020). Dr Tredos, the director-general of WHO, says "During the most recent Ebola epidemic, for example, some medicines that were thought to be effective were found not to be as effective as other medicines when they were compared during a clinical trial" (Ghebreyesus, 2020). It appeared in Wuhan city of China on 12 Dec 2019 (Sahin, Erdogan, Agaoglu, Dineri, \& Cakirci, 2020). Although COVID-19 has a similar spread with SARS and MERS, it exhibits lower mortality rates (Sahin, Erdogan, Agaoglu, Dineri, \& Cakirci, 2020, p. 5). A review of EJMO 
ISSN: 2362-1303 (Paper) | eISSN: 2362-1311 (Online)

JOURNAL OF ADVANCED ACADEMIC RESEARCH (JAAR)

June 2020

introduces it as a new because of no accurate matching with SARS and MERS found before in China; here is a report:

Coronaviruses (CoV) belong to the genus Coronavirusin the Coronaviridae. All CoVs are pleomorphicRNA viruses characteristically containing crownshapepeplomers with 80-160 $\mathrm{nM}$ in size and 27-32 $\mathrm{kb}$ positivepolarity.Recombination rates of CoVs are very high because ofconstantly developing transcription errors andRNA Dependent RNA Polymerase (RdRP) jumps. With itshigh mutation rate, Coronaviruses are zoonotic pathogensthat are present in humans and various animals with awide range of clinical features from asymptomatic courseto requirement of hospitalization in the intensive care unit;causing infections in respiratory, gastrointestinal, hepaticand neurologic systems.They were not considered ashighly pathogenic for humans until they have been seenwith the severe acute respiratory syndrome (SARS) in theGuangdong state of China for the first time in 2002 and2003. Before these outbreaks, there were the two mostknown types of CoV as CoV OC43 and CoV 229E that havemostly caused mild infections in people with an adequateimmune system.Approximately ten years after SARS thistime, another highly pathogenic CoV, Middle East RespiratorySyndrome Coronavirus (MERS-CoV) has emerged inthe Middle East countries. In December 2019, 2019 novelCoronavirus (nCoV), which is another public health problem, has emerged in the Huanan Seafood Market, wherelivestock animals are also traded, in Wuhan State of HubeiProvince in China and has been the focus of global attentiondue to a pneumonia epidemic of unknown cause. At first, an unknown pneumonia case was detected onDecember 12, 2019, and possible influenza and other coronaviruses were ruled out by laboratory testing. Chinese authoritiesannounced on January 7, 2020 that a new type ofCoronavirus (novel Coronavirus, nCoV) was isolated.Thisvirus was named as COVID-19 by WHO on January 12 andCOVID-19 on 11 February 2020. As of February 12, 2020, a total of 43.103 confirmed cases and 1.018 deaths havebeen announced.[8] When given where the first case originated,the infection were transmitted probably as zoonoticagent (from animal to human). The increase in the numberof cases in Wuhan city and internationally after closing themarket and evacuation of the cases in China, has indicateda second transmission from human-to-human. New casesare identified, primarily in other Asian countries and inmany countries such as the trans-oceanic USA and France(Sahin, Erdogan, Agaoglu, Dineri, \& Cakirci, 2020).

It is the first worldwide lockdown because of the virus since American precedent Donald Trump announced lockdown in America on 30 March 2020. According to the nature of its massive spread or a pandemic quality, physical isolation is the most useful remedy for controlling the expansion of it (Shiong, 2020). It is very difficult to control although it does not spread in the air. Its mortality rate is low in comparison with other viruses (Sahin et al., 2020). The Director General of WHO (Ghebreyesus, 2020) has given 
40 guidelines of precautions which are very simple like to wash hands with water and soap; to keep a social distance; to use mask etc. saying COVID-19 is an enemy of humanity. FIFA and WHO have campaigned to promote five key steps for people as follows: "The 'Pass the message to kick out coronavirus' campaign promotes five key steps for people to follow to protect their health in line with WHO guidance, focused on hand-washing, coughing etiquette, not touching your face, physical distance and staying home if feeling unwell" (FIFA \& WHO, 2020). Research (Ku, Ng, \& Lin, 2020) in China have discovered that lockdown effectively controlled the coronavirus in Wuhan. Many types of research have been conducted regarding the invention and adverse effect of it to the human civilization (Soon-Shiong, 2020). After studying the existed literature or researches, the answers of the questions "Is human safe without inventing vaccine or medicine of COVID19 applying the only five key steps? If yes, how does it work? Or can coronavirus be a lesson to moralize and lead to independency for human?" are sought in this research.

Although scientists have been still unable to invent the medicine or vaccine of COVID-19, they have made tremendous progress in the study of it. They have revealed the nature of it like: it is built with fat; it is RNA; it does not pass by air; it is damaged by soap; it passes with droplets from infected persons etc. because of which they are successful in controlling it so far from being the massive infection around the world (Soon-Shiong, 2020). WHO Director-general says, "A vaccine is still at least 12 to 18 months away" (Ghebreyesus, 2020). This means that inventors are rigorously working for detection of the medicines to an effective and operational cure. Studies and research have done up to now are blessing for the human to be safe. Until we achieve more than this we have to utilize the available knowledge and resources. So, many countries of the world started lockdown in the recommendation of the World Health Organization from $24^{\text {th }}$ March 2020. China locked down Wuhan city and got a victory on it ( $\mathrm{Ku}$ et al., 2020). Italy was suffered highly at the beginning because of ineffective lockdown. America also faced the same problems. Studying the result of the effective lockdown, we have to accept that lockdown is inevitable means to save human life. Therefore the lockdown is only the preeminent weapon to triumph over corona and it is the inevitable condition that we must endure despite our indifference. The hypothesis is that trivial lockdown encourages dependent society or country to be independent. Similarly, rules for physical distance help people to develop skills, to be self-disciplined, and to improve in manner.

Although the case of coronavirus has occurred recently, there are sufficient researches and studies about it. Most researches have basically focused on prediction and control of it, the search of vaccine and medicines, many investigations for searching the effective remedies but I could hardly find the study on 'Benefit of the Lockdown Because of COVID-19, Coronaviruses. The study may help to escalate up from the point whatever we have achieved.

In an effort to prevent the outbreak from further spreading, the central government of 
ISSN: 2362-1303 (Paper) | eISSN: 2362-1311 (Online)

JOURNAL OF ADVANCED ACADEMIC RESEARCH (JAAR)

June 2020

China imposed a lockdown in Wuhan and other cities in Hubei on 23rd January. The airport, railway station, and metro of Wuhan were all suspended, and major highways were closed. The lockdown of a city of the size of 11 million residents for the purpose of outbreak control was an unprecedented public health measure (Ku, Ng, \& Lin, 2020).

News about 'the importance of social distancing ${ }^{1}$ has said that COVID-19 is a widespread communicable diseases from person to person. According to the news, physical distancing is the most useful way to prevent from being pandemic. Just contradictory the rule of the social or physical distancing, news about India (Sky News, 2020) shows unmanageable crowd the after lockdown was declared by the Indian government.

Lockdown, social distancing/physical distancing and quarantine are the remedies to prevent COVID-19 passing from each other. So, people often think that these terms are the same but they are completely different things. Lockdown can be done in different cells. Lockdown can be operative at border or airport of international flight. It can be effective in province wise of inner country's territories. It can be inter-administrative areas or villages. The main aim of lockdown is to prohibit human enter from a particular area to another with the present case of deadly virus COVID-19. Here a home can also be the smallest cell or unit of lockdown for a human. Social distancing means that there should be a certain space between two people either inside or outside of the lockdown areas. In medical contexts, isolation specifically means the complete separation from others of a person suffering from contagious or infectious disease (Kelly, n.d.). Quarantine is a designated place for the people who are being investigated up a certain time. A quarantine is a strict isolation imposed to prevent the spread of disease (Kelly, n.d.).

\section{What is the difference between social distancing and physical distancing?}

Some health professionals are increasingly encouraging the use of the term physical distancing as a clearer alternative to social distancing. Physical distancing underscores the importance of keeping physical distance between people to help stop the spread of the coronavirus. The term additionally makes clear that people should still spend time with friends and family using digital technology and social media when they are physically separated (Kelly, n.d.).

For all the three types of circumstances, instructions should be followed by the people stated by the government to take action to combat the pandemic. There is no doubt; the government of a country had to take immediate and audacious decision studying the nature of communicable diseases like COVID-19. A study has believed that it does not pass from animal to animals. Several studies have admitted that it does not pass through air (Shiong, 2020). Researchers have confirmed that it passes from an infected person by contamination while touching and with droplets produced from mouth and noses (Soon-Shiong, 2020). Studying the nature of its transmission, the power of the whole world could not discontinue people travelling 
through and out from Wuhan of China to the world. It could not have been difficult. In the case of escaping some people from Wuhan, they weren't forced to inform the authorities to have come out from Wuhan. The government of the related country should keep them in quarantine for the period up to the date of COVID-19 off. It was easier to search for the people at that time. Before lockdown announced, WHO didn't announce that the person who had come out of Wuhan will be awarded if they inform to a designated contact number keeping a certain notice centre. The person can be kept in quarantine.

Here are some habits that should be tested. These common habits include:

Using spit to count notes (paper money)

Using spit while changing paper sheet

Biting fingernail

Chewing pen while writing

Chewing bubblegum making bubbles

Kissing and hugging

Shaking hands

Coughing and sneezing without covering

Eating food sharing the plate

Taking food without washing hand

Clearing throat and sneezing in public

Touching nose with fingers without napkin or handkerchief

Clearing nose without washing hands

Pressing eyes with the unwashed hand

\section{METHOD}

To study human society, it is important to cover both types of living style i.e. backward village and developed urban area. The population of the study must be the achievers who have passed life in that of the very backward society and enjoying the advanced life in cities as well. The sample size is suitable if it is taken the types of the population who answer the questions of adaptation in both types of areas. In a remote village of Makawanpur, Aambhanjyang, there are around 200 populations who have passed a very difficult life of a remote village and at present, they have been living at a town, Hetauda. They have experience of both types of societies. Among $10 \%$ of them or 20 persons from the village is the sample size for the study. They can present the problems or answers the questions related to the experience of town and village. The data were analyzed in SPSS for evaluating and reporting the fact. Likert scale methods were used for qualitative data. Mean, one sample tests, chi-square tests were checked for studying the data. The questionnaire is sent by messenger/email because of lockdown for the safety measure of coronavirus infections. Among the twenty respondents, there are eleven female and 9 male people. The sample has been taken randomly. Majority of them are highly educated with above +2 level educations. They have nearly passed the equal time in village and town. More than average persons are jobholders. 


\section{RESULT AND DISCUSSION}

Table 1: Gender of the Participants

\begin{tabular}{|ll|l|l|l|l|}
\hline & & $\begin{array}{l}\text { Frequen } \\
\text { cy }\end{array}$ & Percent & $\begin{array}{l}\text { Valid } \\
\text { Percent }\end{array}$ & $\begin{array}{l}\text { Cumulative } \\
\text { Percent }\end{array}$ \\
\hline Vali & Male & 9 & 45.0 & 45.0 & 45.0 \\
d & Femal & 11 & 55.0 & 55.0 & 100.0 \\
& e & & & & \\
& Total & 20 & 100.0 & 100.0 & \\
\hline
\end{tabular}

In this study, $85 \%$ of people were used to in handshaking, hugging, kissing, and physical touch when they meet friends and relative $70 \%$ people were used to in counting money with spit finger. $70 \%$ of people had the habit of turning pages of paper with spit finger (Fig 1). $45 \%$ people touch faces anytime with hands (Fig 2). Now, this study has proved that the habits are risky and the culture of doing Namaste/Namaskar for salutation is less risky free from COVID-19, 95\% people believe that they change their manner when they practice for the rules to save from Coronavirus

Table 2: Education of Participants

\begin{tabular}{|ll|r|r|r|r|}
\hline & $\begin{array}{c}\text { Frequenc } \\
\mathrm{y}\end{array}$ & Percent & \multicolumn{1}{|c|}{$\begin{array}{c}\text { Valid } \\
\text { Percent }\end{array}$} & \multicolumn{2}{|c|}{ Cumulative Percent } \\
\hline Vali & School & 3 & 15.0 & 15.0 & 15.0 \\
$\mathrm{~d}$ & level & 2 & 10.0 & 10.0 & 25.0 \\
& +2 & 3 & 15.0 & 15.0 & 40.0 \\
& Bachelor & 12 & 60.0 & 60.0 & 100.0 \\
Master's+ & 20 & 100.0 & 100.0 & \\
Total & &
\end{tabular}

COVID-19.

They also believe that after long lime of practice the habit can be the culture which was the traditional culture and discipline as well of their society. 
ISSN: 2362-1303 (Paper) | eISSN: 2362-1311 (Online)

JOURNAL OF ADVANCED ACADEMIC RESEARCH (JAAR)

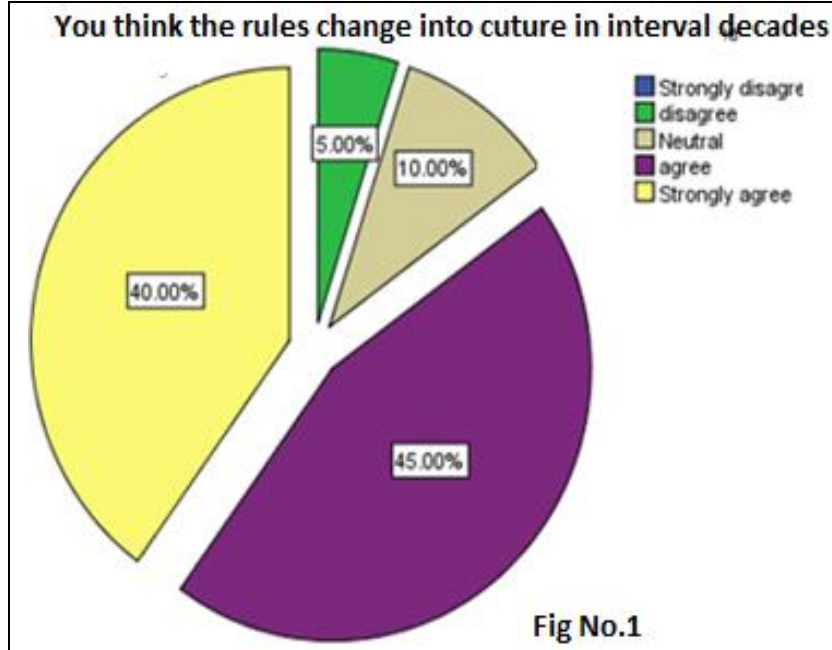

You used to do hand shaking, kissing , and sometimes both when you meet someone you know

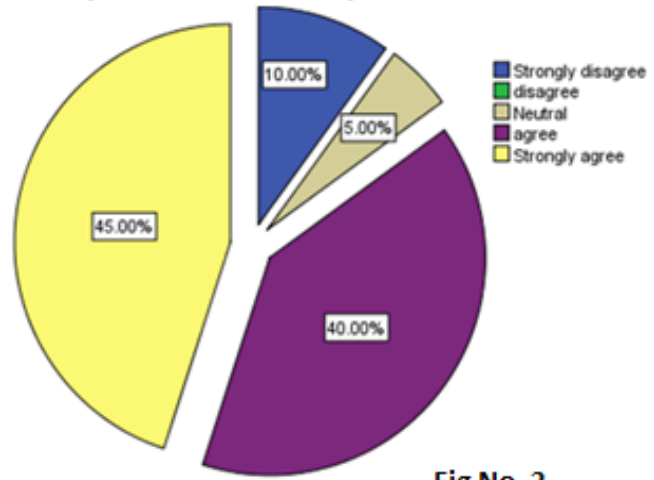

Fig No. 2

One has to be self-disciplined to follow the rules accurately (Fig 3). Cent percent of the people agrees that the rules can be followed when everyone is in self-discipline. With the force of government and the law of court cannot make people follow the rules although the breaching of the rules is the risk for them (Fig 4).

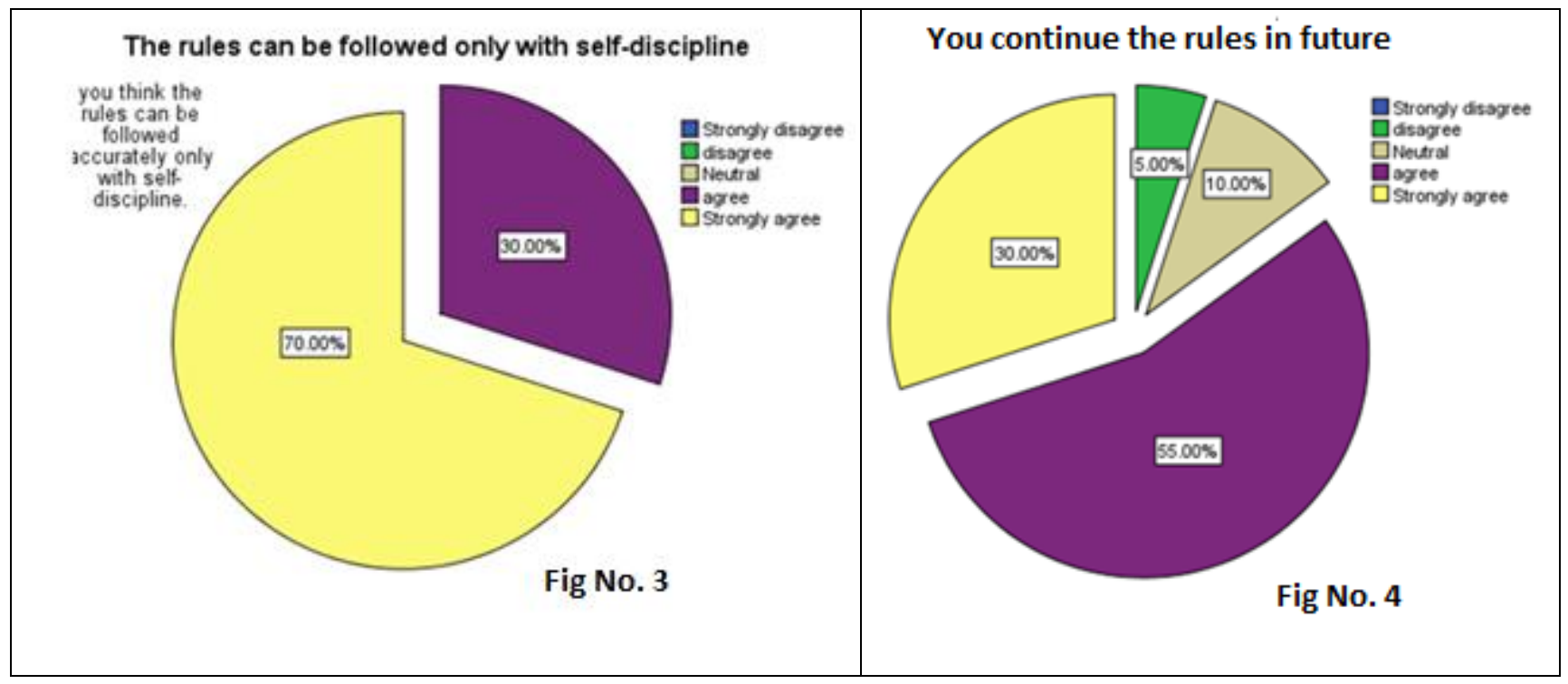

All the foods we eat come from two sources i.e. plants and animals except salt and water. Farmers can grow everything but not salt. Nepal was independent in cotton and clothes. For the critical condition like lockdown longer than three months, farmers can grow livelihood themselves. During the critical period, the value of money cannot be compared with food. Job holders are badly affected and the government also cannot control the wrongdoing in the circumstances. The study proves the farmers who grow agriculture product are safer than job holder. One of the most useful lessons of the lockdown, according to respondents, is independency without leaving the 
ISSN: 2362-1303 (Paper) | eISSN: 2362-1311 (Online)

JOURNAL OF ADVANCED ACADEMIC RESEARCH (JAAR)

June 2020

farming either in town area or in the village. The pie chart (Fig 5) shows that $90 \%$ of people accept that farmers are safer than job holders during long time lock. There are not more difficulties in the village for physical distancing besides working in the field. If farmers can to produce keeping the physical distancing, all the people of another profession too can survive.

All respondents have learned the rules for preventive measures from spreading the COVID19. Among the respondents, $70 \%$ think that all the five rules prescribed by WHO are followed. $20 \%$ of them are giving emphases to washing hand with soap, and $10 \%$ of them believe in physical distancing (Fig 6).

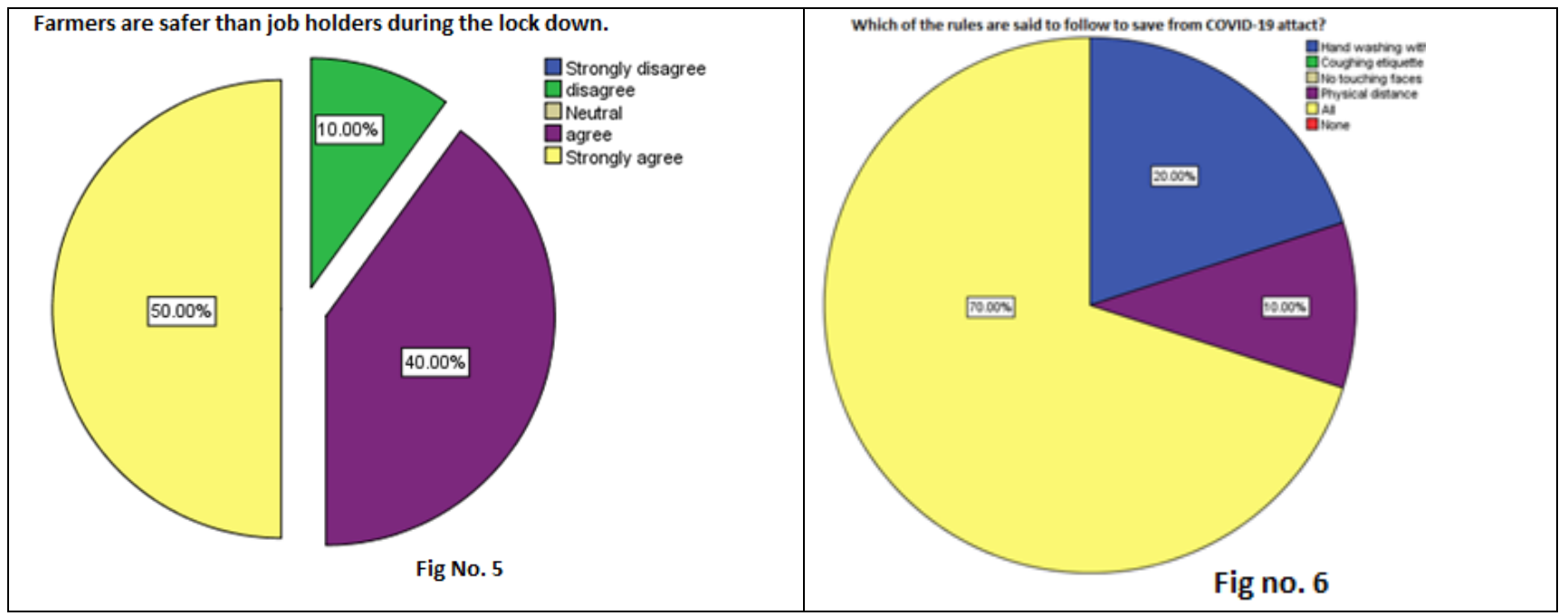


Means of all questions, in Table 3, are higher than predetermined mean 3 except the third question. In the question of which rules they follow to save from COVID-19, the mean is 4.1 which is higher than 3. The mean difference of the question is 1.1 . In the answer to the question which habit they are difficult the mean is 4 . The mean difference is 1 . So, they don't have difficulties following the applying rules. The mean of the third question as if they were following the rules; the mean of the question is below 3. Mean difference is in negative. It is clear that they were not washing hands with soap etc. regularly. In the question, if they follow the rules in future, the mean may be higher than 3 . So, it proves that people are being skillful, following good manners and being self-disciplined in future.

Table 3: Mean of the five rules Of WHO guidance focused on hand washing, coughing, coughing etiquette, and not touching faces

\begin{tabular}{|c|c|c|c|c|}
\hline & $\begin{array}{l}\text { Which of the } \\
\text { rules are said to } \\
\text { follow to save } \\
\text { from covid-19 } \\
\text { attack? }\end{array}$ & $\begin{array}{l}\text { Which habits are } \\
\text { very difficult to } \\
\text { perform for } \\
\text { health care? }\end{array}$ & $\begin{array}{l}\text { Which rules were } \\
\text { you accurately } \\
\text { performing before } \\
\text { the corona attack? }\end{array}$ & $\begin{array}{l}\text { Which of the rules do } \\
\text { you follow in future if } \\
\text { you and your family } \\
\text { are safe from covid- } \\
19 ?\end{array}$ \\
\hline Mean & 4.1000 & 4.00 & 2.1000 & 3.3000 \\
\hline $\mathrm{N}$ & 20 & 20 & 20 & 20 \\
\hline Std. & & & & \\
\hline Deviatio & 1.61897 & 1.257 & 1.91669 & 1.80933 \\
\hline & & & & \\
\hline
\end{tabular}

According to the report of the Table $4 \mathrm{a}, 4 \mathrm{~b}$ and $4 \mathrm{c}$, mean of the questions; you continue the rules in future; it is easy to perform the prescribed rules in the village than town; you always used to do hand shaking, namaste and sometimes both when you meet someone you know in daily life; you used to count money with spit; you used to touch your faces any time; you used to turn paper sheets with spit; Long period lockdown forces people to grow livelihood themselves; Farmers are safer than job holders during the lock down; It is easier for people in town to manage life at village for a long term lock down than vice versa; people in village are independent in food than people in town; Lockdown like the period of COVID -19 attack encourages people to be independent; Long period lockdown forces people to grow livelihood themselves; Farmers are safer than job holders during the lock down; It is easier for people in town to manage life at village for a long term 
ISSN: 2362-1303 (Paper) | eISSN: 2362-1311 (Online)

JOURNAL OF ADVANCED ACADEMIC RESEARCH (JAAR)

June 2020

lockdown than vice versa; people in village are independent in food than people in town; Lockdown like the period of COVID -19 attack encourages people to be independent secured mean values:3.4500, 4.1000, 4.1000, 3.2500, 3.7500, 3.5000, 4.2500, 4.3000, 3.4500, 4.6000, 4.0000, $4.2500,4.3000,3.4500,4.6000$, and 4.0000 respectively. All the research factors have got higher than the average value. The result concludes that the respondents are positive on the matter of the questions.

Table 4 a: Mean of the habit, skills, and manner

\begin{tabular}{|c|c|c|c|c|c|c|}
\hline & $\begin{array}{l}\text { It is easy to } \\
\text { perform the } \\
\text { prescribed } \\
\text { rules in the } \\
\text { village than } \\
\text { town. }\end{array}$ & $\begin{array}{l} \\
\text { You continue } \\
\text { the rules in } \\
\text { future. }\end{array}$ & $\begin{array}{c}\text { You always } \\
\text { used to do } \\
\text { hand shaking, } \\
\text { namaste and } \\
\text { sometimes } \\
\text { both when } \\
\text { you meet } \\
\text { someone you } \\
\text { know in daily } \\
\text { life. }\end{array}$ & $\begin{array}{l}\text { You used to } \\
\text { count } \\
\text { money with } \\
\text { spit. }\end{array}$ & $\begin{array}{l}\text { You used } \\
\text { to touch } \\
\text { your faces } \\
\text { any time. }\end{array}$ & $\begin{array}{l}\text { You used to } \\
\text { turn paper } \\
\text { sheets with } \\
\text { spit. }\end{array}$ \\
\hline Mean & 3.4500 & 4.1000 & 4.1000 & 3.2500 & 3.7500 & 3.5000 \\
\hline $\mathrm{N}$ & 20 & 20 & 20 & 20 & 20 & 20 \\
\hline $\begin{array}{l}\text { Std. } \\
\text { Deviation }\end{array}$ & 1.14593 & .78807 & 1.20961 & 1.40955 & 1.06992 & 1.19208 \\
\hline
\end{tabular}

Table 4 b: Mean of the habit, skills, and manner

\begin{tabular}{|c|c|c|c|c|c|c|}
\hline & $\begin{array}{l}\text { You used to } \\
\text { clean nose } \\
\text { with fingers } \\
\text { without } \\
\text { washing } \\
\text { hands with } \\
\text { soap. }\end{array}$ & $\begin{array}{l} \\
\text { You think the } \\
\text { rules need } \\
\text { skill/habit. }\end{array}$ & $\begin{array}{l}\text { You think the } \\
\text { rules can be } \\
\text { followed } \\
\text { accurately } \\
\text { only with } \\
\text { self- } \\
\text { discipline. }\end{array}$ & $\begin{array}{l}\text { You think the } \\
\text { rules improve } \\
\text { manner. }\end{array}$ & $\begin{array}{l}\text { You think the } \\
\text { rules change } \\
\text { in culture } \\
\text { after long } \\
\text { time }\end{array}$ & $\begin{array}{l}\text { Life during } \\
\text { lock down is } \\
\text { more difficult } \\
\text { in town than } \\
\text { in village. }\end{array}$ \\
\hline Mean & 2.9000 & 4.3000 & 4.7000 & 4.6500 & 4.2000 & 4.3500 \\
\hline $\mathrm{N}$ & 20 & 20 & 20 & 20 & 20 & 20 \\
\hline $\begin{array}{l}\text { Std. } \\
\text { Deviation }\end{array}$ & .96791 & .73270 & .47016 & .58714 & .83351 & .81273 \\
\hline
\end{tabular}


Table 4 b: Mean of the habit, skills, and manner

\begin{tabular}{|l|r|r|r|r|r|}
\hline & $\begin{array}{c}\text { Long period } \\
\text { lock down } \\
\text { forces people } \\
\text { to grow } \\
\text { livelihood } \\
\text { themselves. }\end{array}$ & $\begin{array}{c}\text { Farmers are } \\
\text { safer than job } \\
\text { holders } \\
\text { during the } \\
\text { lock down. }\end{array}$ & $\begin{array}{c}\text { It is easier for } \\
\text { people in } \\
\text { town to } \\
\text { manage life } \\
\text { at village for } \\
\text { a long term } \\
\text { lock down } \\
\text { than vice } \\
\text { versa. }\end{array}$ & $\begin{array}{c}\text { in food than } \\
\text { people in } \\
\text { town. }\end{array}$ & $\begin{array}{c}\text { voople in } \\
\text { independent } \\
\text { like the } \\
\text { period of } \\
\text { covid -19 } \\
\text { attack } \\
\text { encourages } \\
\text { people to be } \\
\text { independent. }\end{array}$ \\
\hline $\begin{array}{l}4.250 \\
\text { Mean }\end{array}$ & 20 & 4.3000 & 3.4500 & 4.6000 & 4.0000 \\
Std. & 20 & 20 & 20 & 20 \\
Deviation & .78640 & .92338 & 1.27630 & .50262 & 1.16980 \\
\hline
\end{tabular}

Table 5: Lock down like period of COVID-19 attack encourages people to be independent One-Sample Test

\begin{tabular}{|c|c|c|c|c|c|c|}
\hline & \multicolumn{6}{|c|}{ Test Value $=2.5$} \\
\hline & \multirow[b]{2}{*}{$\mathrm{T}$} & \multirow[b]{2}{*}{ df } & \multirow{2}{*}{$\begin{array}{l}\text { Sig. }(2- \\
\text { tailed) }\end{array}$} & \multirow{2}{*}{$\begin{array}{c}\text { Mean } \\
\text { Difference }\end{array}$} & \multicolumn{2}{|c|}{$\begin{array}{l}95 \% \text { Confidence Interval } \\
\text { of the Difference }\end{array}$} \\
\hline & & & & & Lower & Upper \\
\hline $\begin{array}{l}\text { Lockdown like the } \\
\text { period of COVID } \\
-19 \text { attacks } \\
\text { encourages people } \\
\text { to be independent. }\end{array}$ & 5.735 & 19 & .000 & 1.50000 & .9525 & 2.0475 \\
\hline
\end{tabular}

The Table 5 concludes that lockdown like the period of COVID-19 attack encourages people to be independent because the $\mathrm{p}$ value is .000 which is smaller than 0.05 .

Table 6: Hypothesis testes gender of the participants

One-Sample Test

\begin{tabular}{|c|c|c|c|c|c|c|}
\hline & \multicolumn{6}{|c|}{ Test Value $=0.5$} \\
\hline & \multirow[b]{2}{*}{$\mathrm{t}$} & \multirow[b]{2}{*}{ Df } & \multirow{2}{*}{$\begin{array}{l}\text { Sig. (2- } \\
\text { tailed) }\end{array}$} & \multirow{2}{*}{$\begin{array}{c}\text { Mean } \\
\text { Difference }\end{array}$} & \multicolumn{2}{|c|}{$\begin{array}{l}\text { 95\% Confidence Interval of } \\
\text { the Difference }\end{array}$} \\
\hline & & & & & Lower & Upper \\
\hline $\begin{array}{l}\text { Gender of the } \\
\text { participant }\end{array}$ & .438 & 19 & .666 & .050 & -.19 & .29 \\
\hline
\end{tabular}


ISSN: 2362-1303 (Paper) | eISSN: 2362-1311 (Online)

JOURNAL OF ADVANCED ACADEMIC RESEARCH (JAAR)

June 2020

There is no significant difference between male and female because value of $\mathrm{p}$ is higher than 0.05 (Table 6).

Table 7: Significant association between the rules improve manner and the rules change in culture after decades long time

Chi-Square Tests

\begin{tabular}{|l|r|r|rr|}
\hline & \multicolumn{1}{|c|}{ Value } & \multicolumn{1}{|c|}{ Df } & Asymp. Sig. (2-sided) \\
\hline Pearson Chi-Square & $3.286^{\mathrm{a}}$ & 6 & & .772 \\
Likelihood Ratio & 3.842 & 6 & .698 \\
Linear-by-Linear & .079 & & 1 & \\
Association & 20 & & & .779 \\
N of Valid Cases & & & \\
\hline
\end{tabular}

a. 10 cells $(83.3 \%)$ have expected count less than 5 . The minimum expected count is .05 .

The value of 0.772 ( $>0.05$ ) shows that there is significant association between the rules improve manner and the rules change in culture after decades long time (Table 7). It concludes that the rules for the prevention from COVID-19 improve manner and the changed manner changes culture after decades.

Table 8: Significant association between the rules need skill/habit and the rules can be followed accurately only with self-discipline

Chi-Square Tests

\begin{tabular}{|l|r|r|rr|}
\hline & Value & df & Asymp. Sig. (2-sided) \\
\hline Pearson Chi-Square & $7.013^{\mathrm{a}}$ & 2 & & .030 \\
Likelihood Ratio & 9.276 & 2 & .010 \\
Linear-by-Linear & 6.404 & 1 & & .011 \\
Association & 20 & & & \\
N of Valid Cases & & & \\
\hline
\end{tabular}

a. 4 cells $(66.7 \%)$ have expected count less than 5 . The minimum expected count is .30 .

The value of the Chi-Square Tests is 0.03 , which is less than 0.05 . So, There is no significant association between the rules need skill/habit and the rules can be followed accurately only with self-discipline. It means skills or habit and self discipline are equally needed to follow the rules. In other word skills without self discipline and self discipline without skills or habit there is no effect (Table 8).

\section{CONCLUSIONS}

Four key steps of WHO guidance i.e. hand washing, coughing etiquette, not touching your face, physical distance are the effective preventive measure until the vaccine is discovered. It is not difficult to perform. It needs skills, habit and discipline. People didn't have proper habits and skills before coronavirus attack.

1. People continue the habits in future. 
2. The habits become culture

3. Habits of hand shaking, kissing, hugging, change into Namaste and habits of touching face, using spit for counting money and turning page are checked.

4. Self discipline, manner and skills are inevitable to follow the rules.

5. People give emphasis to farming for food independency.

6. The persons who ignore the rules may die of covid-19 and make others die.

7. Covid-19 goes on recurring forever until and unless whole people of the world accurately follow the rules.

8. Covid-19 disappears if everyone follows the rules.

9. The most important basic need is food during lockdown.

10. Village life is safer that town for food.

11. Lockdown cannot go on continue forever.

12. Health education is inevitable.

13. Farming is the best job.

14. The rules help for precaution for other communicable diseases that passes from touch and droplets.

15. It decreases the expenses of feasts and gatherings.

\section{LIMITATION}

This research has ignored the problem of maintaining the physical distance between the infant and mother. It lacks the study of the problems of foreign job. The study does not include the natural rules and the Malthusian theory of Population.

\section{RECOMMENDATION}

There is no harm to follow the rules for preventive measures of COVID-19 but useful to save from many other communicable diseases. A nation must be independent in food for the circumstance like lockdown. Everyone must be much disciplined in the following the rules of health care. Breaching the rules of health care is a crime. Health education is the most important. Health education must be a compulsory subject. The rules for preventing corona, COVID-19, should be followed by culture. Farming should be continuing during the lockdown period as well.

\section{REFERENCES}

FIFA \& WHO (Performers). (2020, March 23). Pass the message: Five steps to kicking out coronavirus. WHO headquarters, Geneva, Switzerland.

Ghebreyesus, D. T. (2020, March 27). Latest updates - Live press conference (Geneva). (media, Interviewer)

Kelly, J. (n.d.). What Is The Difference Between "Quarantine” And "Isolation"?

$\mathrm{Ku}$, C.C., Ng, T.C., \& Lin, H.H. (2020). Epidemiological benchmarks of the COVID-19 outbreak control in China after Wuhan's lockdown: a modelling. University of Sheffield, 1-16. 
ISSN: 2362-1303 (Paper) | eISSN: 2362-1311 (Online)

JOURNAL OF ADVANCED ACADEMIC RESEARCH (JAAR)

June 2020

Los Angeles Times. (2020, March 18). The Science Behind the Coronavirus, Series I [Video file]. Retrieved from https://youtu.be/ddlRvqhGdPk

Sahin, A. R., Erdogan, A., Agaoglu, P. M., Dineri, Y., \& Cakirci, A. Y. (2020). 2019 Novel Coronavirus (COVID-19) Outbreak:. EJMO , 1-7.

Sky News. (2020, March 29). Coronavirus fear grips workers in India [Video file]. Retrieved from https://youtu.be/6439aOtzEWs 